Audriy Shevannisa Daya

S130119026@student.ubaya.ac.id

\title{
Penerapan Long-Term Care di Berbagai Negara
}

Dalam pelaksanaannya di Indonesia, prinsip Availability, Accessibility, Acceptability, Quality, Inclusiveness \& Non-Diskriminasi diterapkan pada Long-Term Care dimana pada pelaksanaanya di Posyandu Lansia Kota Surabaya \& Malang untuk penyuluhan serta pemeriksaan kesehatan lansia (Pratono, Maharani, 2018). Melalui pendekatan kualitatif terlihat bahwa dalam prinsip Availability \& Accessibility pada puskesmas \& posyandu lansia yang tersedia dan mudah di akses oleh lansia karena pelayanan maupun lokasinya yang mudah dijangkau. Pada prinsip Quality, puskesmas \& posyandu tentunya telah memenuhi standart kesehatan dengan baik, memberikan perhatian khusus hingga mampu mengerti \& melayani para lansia. Puskesmas \& Posyandu Lansia melaksanakan prinsip Acceptability dengan menerima pasien lansia. Serta Inclusiveness \& Non-Diskriminasi, dimana layanan kesehatan tidak melakukan diskriminasi lansia tetapi juga menerima pasien non-lansia.

Berbeda dengan Indonesia, layanan untuk lansia di negara Eropa dikelompokkan menjadi Perawatan Informal dengan pengasuhan dari keluarga, kerabat atau pengasuh khusus lansia, sedangkan pada Perawatan Formal seperti panti jompo. Pemerintah juga membagi 3 tipe perawatan kesehatan bagi lansia yaitu Crowding Out \& Crowding In dimana negara menanggung semua layanan kesehatan lansia serta Mixed Responsibility yang berarti negara dan keluarga lansia terkait memiliki tanggung jawab bersama untuk bertanggung jawab terhadap layanan perawatan \& kesehatan lansia. Di China, layanan kesehatan \& perawatan lansia dilakukan dengan penerapan budaya dimana sudah sewajarnya keluarga terutama anak yang mengurus termasuk keperluan rutin medical check-up maupun fasilitas penyembuhan di rumah sakit.

Bapak Subagyo berumur 69 tahun adalah narasumber yang saya pilih dalam wawancara kali ini. Beliau merupakan kakek dari pihak ibu saya yang memiliki latar belakang pendidikan lulusan SMA dan saat ini menetap bersama istrinya di Kota Surabaya. Beberapa minggu lalu, beliau terkena salah satu gejala Covid-19 yaitu flu berat dan hanya dapat mengikuti protokol kesehatan dengan penanganan mandiri seperti karantina mandiri dan setelah melakukan swab test menunjukkan hasil negative Covid-19. Para lansia mendapatkan layanan kesehatan dengan baik sebelum pandemi, misalnya dengan melakukan cek tensi \& kadar gula darah secara rutin 
di puskesmas \& posyandu lansia serta check up laboratorium \& konsultasi dokter bagi lansia yang masih sanggup secara ekonomi.

Berbeda halnya dengan layanan kesehatan selama pandemi Covid-19 yang tidak sebaik keadaan normal seperti sebelumnya, masyarakat maupun lansia harus melakukan penanganan mandiri dengan karantina \& swab test apabila sedang sakit terutama dengan gejala ringan Covid-19. Tentunya layanan kesehatan saat pandemi berlangsung tidak sepenunya memenuhi prinsip-prinsip dalam layanan kesehatan lansia seperti Availability, Accessibility, Acceptability, Quality, Inclusiveness \& Non-Diskriminasi karena saat ini layanan kesehatan terbatas beserta dengan banyaknya protokol kesehatan yang harus dijalani. Hal itu dikarenakan saat ini yang menjadi prioritas layanan kesehatan seperti rumah sakit ialah pasien dengan gejala berat Covid-19.

\section{REFERENCES}

Evandro, F. F., Xie, C., Schenkel, J. A., Wu, C., Long, Q., Cui, H., .. Woo, J. (2020). A Research Agenda for Ageing in CHina in the 21st Century (2nd edition): Focusing on Basic Policy and Social Networks. Journal Pre-Proof: Ageing Research Reviews, 62.

Pratono, A. H., \& Maharani, A. (2018). Long-Term Care in Indonesia: The Role of Integrated Service Post for Elderly. Journal of Aging and Health, 30(10), 1556-1573. 